\title{
Reverence Thyself-Moral Conscientiousness of the Lost Generation
}

\author{
Author: Dr. K. Sarojadevi, Professor \\ Humanities \& Sciences, Narayana Engineering College, Nellore, A.P, India
}

\begin{abstract}
The aim of this research paper is to explore the vital role of conscience in the lives of human beings. Preached by Joseph Butler, the philosophy of conscience states that the authentic and ultimate guide to human beings in the issues and conflicts of morality is his conscience. This innate mentor pricks people in their thoughts and deeds, which lead them towards the right path. As it is prevalent in every generation, this paper tries to focus its existence in the fiction of the "Lost Generation" in America.
\end{abstract}

Keywords: Appetite, Conscience, Morality, Reverence, Self-Love.

\section{Introduction:}

According to Joseph Butler's philosophy viz Conscience, every human being is an individual moral agent. He is the only one who is being endowed with the faculty of discrimination among all the creatures. This faculty of conscience should guide the human beings in all walks of life. All human instincts, passions and appetites have to yield themselves, to this supreme principle of reflection or conscience for achieving morality. That is why one has to respect his inner guide as 'Reverence Thy self'.

Every human being has similar qualities and principles, which have their own implications. All these sum up the internal constitution with relevant significance. The appetites, emotions and particular affections of our inner self are subject to the authority of conscience or the supreme principle of reflection. The amalgamation of all these qualities and principles thus comes under the moral constitution of man. The body may be injured, a tree may decay, a system may be out of order, and yet the constitution of them is not totally dissolved. The constitution with the presence of the supreme authority i.e. conscience comes to the rescue of any system in emergency. This proportion is just and perfect, as all these principles are relatively in coincidence with conscience. This conscience guides all the walks of life, so far as their nature permits, in right direction. Any deviation from the guidance of conscience leads to some disorder in the moral constitution.

The moral systems, in the early stages of development, are little differentiated from the accompanying theological systems. One can see this in the works of the Stoics as well as in the works of certain Christian moralists. Among the recent ones, one may instance the Essays on the Principles of Morality, by Jonathan Dymond, a Quaker, which makes the authority of the Deity the sole ground of duty, and His communicated will the only ultimate standard of right and wrong. Nor is it by writers belonging to so relatively unphilosophical a sect only, that this view is held; it is held with a difference by writers belonging to sects contrariwise distinguished. For these assert that in the absence of belief in a deity, there would be no moral guidance; and this amounts to asserting that moral truths have no other origin than the will of God, which, if not considered as revealed in sacred writings, must be considered as revealed in conscience. (Spencer 84)

But as the world itself is imperfect, perfection is unattainable. The supreme principle of reflection or conscience can retain its authority, reform the erroneous and execute its power only in a moral person. That man is considered to be good, worthy and virtuous only when his appetites and passions have been maintained in their due proportions. Then only that man is said to have achieved mastery over all other principles through the power of conscience.

Joseph Butler has proposed his moral philosophy with conscience as the supreme authority. His theory is based upon a keen observation of human nature by conscience. In his findings, Butler thinks that man is a complex psychological being. He acts with the help of different principles among which conscience is the highest in authority and the greatest in strength. Even though he states that it is the principle of reflection and calls it a rational faculty, he never clearly explains its relevance. No philosopher demonstrates how and why these dictates of conscience should govern our moral conduct. One may conclude that as its very purpose is self-evident, it needed no demonstration. "To affirm that we know some things to be right and other things to be wrong, by virtue of a supernaturally given conscience; and thus tacitly to affirm that we do not otherwise know right from wrong; is tacitly to deny any natural relations between acts and results." (Spencer 89)

Appetites, passions, affections, considered merely as the several parts of our inward nature, do not at all give us an idea of the system or constitution of this nature. Because the constitution is formed by the relations these several parts have to each other; the chief of which is the authority of reflection or conscience. It is from considering the relations which the several appetites and passions in the inward frame have to each other, and 
above all, the supremacy of reflection or conscience, that we get the idea of the system or constitution of human nature. And from the idea itself it will as fully appear, that this nature, i.e., constitution is adapted to virtue, as from the idea of a clock it appears, that its nature i.e., constitution or system is adapted to measure time.

A majority of mankind good as well as bad also obey their instincts and principles according to the same rules, namely the constitution of their body and the external circumstances which they are in. Therefore, it is not a true representation of mankind. They are completely motivated and governed by self-love, the love of power and sensual appetites. On one hand, they are motivated by these appetites, without any regard to right or wrong. On the other hand, some people are motivated by friendship, compassion, gratitude and justice. This is the partial inadequate notion of human nature and it is by this nature, that the world is in fact influenced, and kept in that tolerable order in which it is.

Neither can any human being is said to act conformably to his constitution of nature, unless he allows to that superior principle the absolute authority which is due to it. The practical reason of emphasizing so much upon this natural authority of the principle of reflection or conscience is that it seems in a great measure neglected by many, who are by no means the worst sort of men. One is supposed to abstain from gross wickedness, and to be humane and kind to one's fellow-beings. The very constitution of human nature requires that human beings bring their whole conduct before their superior faculty, wait its determination and enforce upon themselves its authority. It is absolutely the whole business of a moral agent. This is the true meaning of that ancient precept, 'Reverence Thyself' i.e. 'Respect Your Soul'.

According to Edkins, conscience is regarded among the Chinese as the supreme authority. He says: When the evidence of a new religion is presented to them they at once refer it to a moral standard, and give their approval with the utmost readiness, if it passes the test. They do not ask whether it is Divine, but whether it is good. (Spencer 353)

The idea of self-love is considered contrary to the faculty of conscience. This is distinguished from various principles such as the appetites of sense, resentment, compassion etc. Epithets may make this distinction as settled selfishness or sensual selfishness. But naturally this self-love generates from the desire towards something external like honour, power, harm or good of another. The pursuit of these external objects makes a man liable for abnormality. Self-love in its due degree is as just and morally good as any other principle. One cannot find any peculiar reason for this self-love, its influence is natural. Every caprice of the imagination, every curiosity of the understanding, every affection of the heart clearly exhibits its influence, by prevailing over it. Yet man always sacrifices his natural instincts to love or hatred. In general men have much regard to the good of others rather than their own. That is why gratification of particular passions unfriendly to benevolence is not prevalent in most of them.

On the whole, if the generality of mankind were to cultivate within themselves the principle of selflove; if they were to accustom themselves often to set down and consider, what was the greatest happiness they were capable of attaining for themselves in this life; and if self-love were so strong and prevalent, as that they would uniformly pursue this, without being diverted from it by any particular passion, it would manifestly prevent numberless follies and vices. This was in a great measure the Epicurean system of philosophy. It is indeed by no means the religious or even moral institution of life. Yet with all the mistakes men would fall into self- interest, it would be less mischievous than the extravagances of mere appetite, will and pleasure for certainly self-love. Though confined to the neither interest of this life, which is a better guide than passion, which has absolutely no bound or measure, man is said to have moral considerations. The superior principle of conscience or reflection in every man, distinguishes between the internal principles of his heart as well as his external actions. This faculty controls self-love natural to man and makes him a moral agent and a law to himself. Marcus Cunliffe confirms that "Nor will it be difficult to find an authority similar to it in the literature of the East: in a critical situation in a play of Kalidas the hero's thought on morality can be translated as under: Of the good people in the situations of doubt the guide should be their inner nature." (n.pag)

Passion or appetite implies a direct simple tendency towards such and such objects, without the distinction of the means by which they are to be obtained. Consequently, it will often happen that there will be desires of particular objects, in cases where they cannot be obtained without certain injury to others. Reflection or conscience, comes in, and disapproves the pursuit of them in these circumstances. Conscience does not only offer itself to show us the way we should walk in, but it likewise carries its own authority with it, that it is our natural guide, the guide assigned us by the author of our nature; it therefore belongs to our condition of being. It's our duty to walk in that path, and follow this guide, without looking about to see whether we may not possibly forsake them with impunity.

This faculty of conscience is being reflected in Fitzgerald's Tender is the Night and Hemingway's The Sun Also Rises and A Farewell to Arms. 


\section{Description:}

Coming to the themes of Fitzgerald, he was very much involved with the life of his time, its feelings and values, its aspirations and anxieties. Even though Fitzgerald was busily engaged in earning, he was careful to the dictates of conscience nurtured by his progenitors of ethical hue. He was completely aware of the moral rottenness of his times and he lamented the same. He wrote to his daughter that "My generation of radicals and breakers down never found anything to take the place of the old virtues of work and courage and the old graces of courtesy and politeness." (36)

While appreciating the unavoidable influence of money on a contented life, he made a distinction between rich young men with unearned wealth and poor young men who craved for a lot, and more often than not, earned wealth. The poor unlike the rich are often made to run the race with psychological handicaps that are too deep-rooted to be ignored even when they win the race. And Fitzgerald's attachment lies always with the poor class for personal reasons. Most of his characters were settled in a heady atmosphere which the twenties could not have escaped. Disillusionment encompasses nearly all of his characters, often accelerating their maturation. According to Hoffman:

In the process of that maturation his characters grew perceptibly older, hardened and eventually become representative images of a class. One can recognize their gaiety to be superficial, and their metaphysical as well as physical distress to be real. That distress was not a matter of chance, but resulted from a fundamental lack of a clear moral sense, a lack really of cultural fact which had caused men in the very beginning to have the wrong dreams, and which gave them no proper way of judging them. (135)

On the whole, one can find in Fitzgerald's characters a tension between values that seem to be anachronisms and dreams, and achievements that seem to be inevitable refusal of those values. The awareness of this conflict seems to invest his characters with a tragic sense that transcends the age in which they are placed, extending far into the future that was still a speculation. Fitzgerald exhibits the noble distress of his characters in the face of defeats brought about by them, through the loss of dignity.

The theme of Tender is the Night is the self-destruction of the protagonist because of his alienation from the stable world of childhood, by his separation of himself from the past, the older world in which he was safer and surer, and by his lack of faith in character which once was an eternally valuable element. The world in which he was brought up was the one with charm, fame, good manners which were weighed more than money as a social asset. This was rather good but things became thinner as the eternal human values tried to scatter over that entire expanse. In this novel, two destructions are interwoven; one is the destruction of a man by his own charm and the other is the destruction of a marriage. The novel is the tragedy of an individual and a society. The corruption worked by wealth upon a man of talent and conscience, is traced in the novel. Driven by conscience, the physician married a rich lady and took care of her for a long time and the wife's backstabbing made him fall into the chasm of corruption and immorality. Tender is the Night is occupied by the incest motifs which symbolize both Dick's loss of allegiance to the moral code of his father and a social situation existing throughout Europe and America during the twenties. In this regard E. Nageswara Rao states that "Tender is the Night is concerned with the inner life of a man and a woman, the disintegration of an integrated personality and the integration of a split one." (20)

Dick Diver and Nicole have been leading a cautiously pampered life for about a decade when one sees them on the beach. It has been such a civilized life that it is supposed to represent the furthermost evolution of a class, for its self-discipline. Still under the veil of this social life, there is a world of dark forces who are striving themselves to be free. The protagonist Dick is a psychiatrist, who married Nicole, the daughter of a famous American business man and they have got a relaxed life on the French Riviera with the wealth of Nicole. Nicole in her mid-teens is subject to spells of eccentricity and as a result she is seduced by her father. Her sister Baby Warren wants to buy Nicole a doctor, Dick. Dick agrees on account of their weakness for each other rather than for money. Still, he has a nagging feeling that he has been used as a piece of ornament in Nicole's life, not for its intrinsic vale but for its presence and utility. Eugene White observes that "He is a brilliant psychiatrist whose life is ruined because he falls in love with the wrong woman and because his vitality is sapped by the abundance of the Warren money."(55)

But he loves Nicole very much, and treats her abnormality with utmost patience. His conscience makes him accept the responsibility of being loved by Nicole, and gradually by all those, his life is weaved around her.

Also Dick is a social charmer. He has the power to bestow carnivals of love upon others and to explore from all a fascinated and uncritical love. Every one is told that to be involved in Dick's world and company was a wonderful experience. Dick has been brought upon older American values which he has acquired from his father, who inherited them from his ancestors. Dick loves his father very much and always refers to his actions or instructions in crisis. He is told about life, matters of behaviour and ethical values by his father. He has been sure of what he is, with a deep pride of the two proud widows who have raised him to believe that nothing could be superior to good instincts, honour and courtesy and courage. Fettler Ley says that: 
Though Dick professes to admire the manners of his father inherited from the days when you shot first and apologized afterward, when he falls back on these manners and avails himself of 'the honorable, the traditional resource of his land,' what happens to him is so awful that nothing could make any difference. . . he was hopeless. He would be a different person henceforward. . . (126)

Though brought upon such commendable values, Dick is a prey to certain weaknesses. And they are respect for money, and a great need to be accepted, admired and loved. His father educated him on his mother's small fortune. Watching his father's struggles made him crave for money, respect and love. "He wanted to be good, he wanted to be kind, he wanted to be brave and wise... He wanted to be loved to if he could fit it in" (Fitzgerald 145). This attitude reflects the concept of self-love in the philosophy of conscience, i.e., that selflove is not love towards oneself, but passion towards some thing external - honour, power or good of another. Human beings tend to yield to self-love in pursuit of some thing external. Hence, it seems that it is ridiculous to blame such a self-alienated person. When the person engaged in it knows before-hand, and goes on under the feeling and apprehension, that it will be as ruinous to him; then he deserves blame. Eugene White Opines that: Mingled thus with the elements in his character which make for greatness, for love and sacrifice and discipline and control, are the elements of weakness and insufficiency, the elements which blur the actions of love and selflessness and confuse them with suggestions of self-gratification and deep-seated need. But it is this very complexity of character and of motive that enriches the story and raises it to the level of the tragic. Dr. Dick Diver is a man who 'is ready to be called to his intricate destiny'. (62)

Though it is Dick's fate to function in a corrupt society, he retains with him a code of morality, the code he has learned from his father and other American values. It is this conscientiousness that makes him reject Rosemary's offer to have an affair with him, on the ground that he wants her to meet her first love 'all intact'. Even Nicole admits that he did not spend a night apart from her since their marriage, except at their child's birth. Dick is a consoler and a resolute moralist to the upper class. He reflects the necessary human values that would remind them of their best selves. His politeness, as he himself admits, 'is a trick of the heart'. Dick has left a little for himself while guiding the rich about dignity. He says that "I have wasted nine years of teaching the rich the ABC's of human decency." (249)

Dick even lost his vitality while helping others; Nicole has become a vampire who got strength by sucking her husband's vitality. But Dick's degeneration originates from his self-love and his attitude to acquire stature and respect. In search of these appetites, he craved for the approval of the society. It is this yearning for acceptance and being loved that appeases his desire to regain that bourgeoisie states which his family, previously occupied. "He has been destroyed by forces he could neither control nor even fully understand, and the moral judgment he had once possessed was of no use." (Contemporary Literary Criticism 76)

The mutual relation between Dick and Nicole is ambivalent as they have commitment to their marriage one side and to satiate their appetites on the other side i.e., For Dick, marriage to Nicole is an opportunity to gain property and respect; where as for Nicole, marriage to Dick is intended mainly for gaining mental wellbeing. Hence, gradually their attachment towards each other began fading. When Nicole found that she does not need his help any more, her love vanishes. Eugene White comments that:

As Nicole comes gradually to a realization that she can stand alone, a new sense of freedom develops within her. She had a sense of being cured and starts feeling in a new way. Her ego began blooming like a rich rose as she scrambled back along the labyrinths in which she had wandered for years. She hated the beach, resented the places where she had played as mother to Dick's son. "Why, I'm almost complete," she thought. "I'm practically standing alone, without him. (308)

And like a happy child, wanting the completion as soon as possible, and knowing vaguely that Dick had planned for her to have it, she wrote Tommy a short provocative letter.

Dick too feels the same; in the words of Doctor Dohmler. "Dick waited until she was out of sight. Then he leaned his head forward on the parapet. The case was finished. Doctor Diver was at liberty again" (317). Dick has inherited good instincts from his father like honour, courtesy and courage. He fell in love with Nicole and married her; even though he knew that she may be a lifelong mental problem for him. But his life begins to lose his control at the betrayal of Nicole. He lost his conscience and vitality in the midst of chaos.

By morality in conventional sense means the degree to which any one conforms in actual practice to the ethical code that, it professes to live by. If a person lives up to its' ethical code to a high degree, then it is moral; if he does not, it is immoral to the extent that it fails. Morality is character and conduct as required by the circle or community in which a man's life happens to be placed.

The traditional conviction that morality was an objective present in the universe was belittled by the First World War. As Hemingway emerged disenchanted from the First World War, he did not follow the standards of conventional morality. "Hemingway's sense of morality" says John Atkins, "is the direct contrast to the dominant puritan one; it is judged by its effects, but moral conduct should bring with it a feeling of fulfillment, not of self-righteousness." (195)

Hemingway's conception of morality is expressed in a simple statement in Death in the Afternoon as what is moral is what one feels good after and what is immoral is what one feels bad after. This reduction of 
ethics to sensation is the general view of the twenties but it is a very limited morality. This is empirical and works a day and not deeply thought, also it is not attached to any principle but it is only an intellectual connection that one should deduce moral principles from rational criteria.

As a novelist Hemingway is often assigned a place among the writers of the "Lost Generation", along with Paul, Fitzgerald, John Dos Passos, Sinclair Lewis, D. H. Lawrence, Sherwood Anderson, T. S. Eliot, Joseph Conrad etc. These writers try to show the loss the First World War had caused in the social, moral and psychological spheres of human life. They also reveal the horror, the fear and the futility of human existence. True, Hemingway has echoed the longings and frustrations that are typical of the writers, but his work is distinctly different from them in its philosophy of life.

The Hemingway hero is a lonely individual, wounded either physically or emotionally. He exemplifies a code of courageous behavior in a world of irrational destruction. He offers up and exemplifies certain principles of honour, courage and endurance in a life of tension and pain which make a man a man. Violence, struggle, suffering and hardships do not make him pessimistic in any way. Though the vague unknown continues to lure him, and frustrate his hopes and purposes, he doesn't admit defeat. Death rather than humiliation, stoical endurance rather than servile submission are the cardinal virtues of the Hemingway hero.

He views life as a perpetual struggle in which the individual has to assert the supremacy of his free will i.e. conscience over forces other than him. In order to assert the dignity of his existence, the individual has to wage a relentless battle against a world which refuses him any identity or fulfillment.

Any action that results in good feelings afterwards is moral and one that results in bad feelings is immoral. In this view of morality, Hemingway relies on the inner-self of a man supposed to be pure and unprejudiced. This is very similar to Emerson's view of good and bad, quoted as "Good and bad are but names readily transferable to that or this; the only right is what is after my constitution, the only wrong, what is against it." (Spencer 89)

The people of Hemingway's novels depend more on their inner nature despite their prejudices and instincts, in practical situations. His morals are not directly preached by him but emerge from situations or from the behavior of people.

One can find both social and moral values in Hemingway's works. The characters follow a certain code for social significance, and also fulfill their social obligations. They are affected by the dictates of conscience and establish their conformity to this supreme guide.

Hemingway attributes the ultimate moral responsibility to the individual in his fiction. He always focuses his attention on the weightage an individual pays to his inner guide i.e. conscience. Benson states that "For Jake, as for Frederic Henry, Robert Jordan, Colonel Cantwell, and Santiago, the essential thing is to "know oneself' and to 'know oneself' is to discipline oneself toward a solid basis for honest feeling." (43)

Hemingway's A Farewell to Arms is an exploration of the protagonist's struggle to retain his dignity amidst his conflict with his inner self. Hemingway as reflected in his works, like many American writers, is always growing up, always becoming a man with conscience. His main characters are always developing characters, the people who realize the significance of their inner guide.

Frederic Henry of A Farewell to Arms is a normal Youngman like many young people of his generation. He is selfish, casual and indifferent in his nature. He seldom shows concern for other's suffering. $\mathrm{He}$ is playful in his activities and does not have faith in moral values. Henry is somewhat a party boy who suffers from a general unawareness. Also fortunately or unfortunately, it is the Italian army that he is attached to, where there is drinking and whoring always.

In his early meetings with Catherine Barkeley, Henry is the casual, careless boy. But inwardly he is of a decent sort. Henry has become sinister because of his playful attitude towards romance. He wants to betray any girl that approaches him. A Farewell to Arms is neither a love story nor a war story; instead it is a modern morality drama. In this, there is a developing consciousness of a young American within the pangs of the context of war. This consciousness brings drastic change in the quality of thinking of Henry. Henry, who is selfish and casual at the beginning, changes his perceptions to become attached and human at the end.

Within the prefixed and self-imposed prison of the self, Henry is unable to respond to others. When the priest asks Henry whether he loves God, he replies 'No', and the priest continues. "You do not love him at all?" 'I am afraid of him in the night sometimes. 'You should love him. 'I don't love much' (Hemingway, A Farewell to Arms 72). Then the priest defines love. He says, "when you love you wish to do things for. You wish to sacrifice for. You wish to serve" (72). Here the priest defines a commitment beyond oneself, beyond the indifferent, unattached condition of Henry at this point in the novel; a commitment Henry will achieve later with the English nurse, Catherine Barkley.

Henry is clear in his introspection; "I know I did not love Catherine Barkley nor had any idea of loving her. This was a game, like bridge, in which you said things instead of playing cards. Like bridge you had to pretend you were playing for money or playing for some stakes. No body had mentioned what the stakes were. It was all right with me" $(30-31)$. 
Catherine is a woman who lost her fiancé in the war. She has been wounded very much emotionally and her sudden outbursts and changes of behavior make Henry to think of her. Henry's discovery of himself begins with his being hit by fragments of a trench mortar shell. Till that, he was a nice boy as Catherine calls him, who urged that defeat is worse than war and who thought of the war as no more dangerous to himself as war in the movies. But when he is hit, he finds that he is really in the war after all; "I tried to breath but my breath would not come and I felt myself rush bodily out of myself and out and out and out and all the time bodily in the wind. I went out swiftly, all of myself, and I knew I was dead and that it had all been a mistake to think you just died"(54). All these reactions mirror the inner conflict of Henry. Like so many young people, Henry is unaware as he is self - imprisoned. Tripathi comments that "The feeling of Frederic Henry for the inefficient doctors, who examine his knee in the hospital at Milan, fail to take any decision and suggest that he should wait for six months, is that of extreme disgust and he shows it by saying that his knee be better cut off." (359).

Henry has been gradually attached to Catherine during the period of his treatment. "Hello, "I said, when I saw her I was in love with her"(91). Henry has signed a contract which lasts till his last breath of life. This personal commitment results only in the loss of his lover. At the same time he also felt a lot for neglecting his primary duty. "I feel like a criminal. I have deserted the army"(218). He has been consoled by Catherine for this repentance.

Catherine need not die as any logical consequence of situations. But love must die. The game is logical, man created but the circumstances are not. By the death of Catherine, Henry loses his balance saying:

Now Catherine would die. That was what you did. You died. You did not know what it was about. You never had time to learn. They threw you in and told you the rules and the first time they caught you off base they killed you or they killed you gratuitously. But they killed you in the end. You could count on that. Stay around and they would kill you (327).

Henry meditates on Catherine's delivery to relieve her of her pains. He is indifferent to God in the initial stages of his life, but circumstances make him realize the power of God. Henry pulls himself together with dignity and grace and survives his own destiny. In course of his life, he emerges as a man of conscientiousness.

A fine illustration of Hemingway's ethics appears in The Sun Also Rises. Jake likes to see Mike hurt Cohn's feelings. In the beginning it made him feel good; but afterwards he feels disgusted. That is morality, whereas things that make one disgusted afterwards came under immorality. Jake Barnes has contradictory feelings within himself. He feels jealous of Cohn for the latter's love of Brett. His jealousy leads to a sense of enjoyment when Mike hurts Cohn. But the feeling of pleasure is momentary and gives place to disgust. The childish feeling of jealousy and revenge is soon overpowered by sympathy and understanding and a sense that no pain should be inflicted on anybody. The notion is not merely theoretical; it is empirically based on inner feeling.

The same test is applied when Jake sees the dance of the homosexuals and Brett joining it. When Cohn asks him, what's the matter with him?, He seems all worked up over something. At this Jake replies, that nothing takes place and that whole show makes him sick. The whole situation is an immoral one because it generates in Jake a feeling of disgust.

Brett's giving up of Romero at the end of the novel is regarded as a moral act in the same sense. Here is a part of the conversation between Brett and Jake:"You know I feel rather damned good, Jake". "You should". "You know it makes one feel rather good deciding not to be a bitch". "Yes" (Hemingway, The Sun Also Rises 22). Brett is thirty four and Romero is a boy of just nineteen with a bright future in bull fighting. Brett's decision is that she is not going to be one of those bitches that ruin children. Her decision is a good one based on conscience.

\section{Conclusion:}

Likewise, even though people at times rush in vain for material pursuits, they probably realize the efficacy of following their inner guide at least at their departure from this world. Such would be the significance of conscience in human life.

\section{References}

[1] Spencer, Herbert. The Principles of Ethics. Vol. I. Indiana Polis: Liberty Fund, 1978

[2] Turn bull, Andrew. The Letters of F. Scott. Fitzgerald. New York: Scribner's, 1953.

[3] Hoffman, J Frederick. The American Novel between Wars.n.p: Henry Regnery Company, 1951.

[4] Nageswara Rao, E. The Critical Pursuit: A Miscellany. New Delhi: Reliance Publishing House, 1994.

[5] White, Eugene. "The Intricate Destiny of Dick Diver". Modern Fiction Studies. Vol. VII (Spring 1961).

[6] Fetterley, Judith. "Who killed Dick Diver, The Sexual Politics of Tender is the Night".

[7] Mosaic. Vol. XVII (Winter 1984).

[8] Fitzgerald, F.Scott. "Tender is the Night", Octopus Books Ltd, 1977.

[9] Cunliffe, Marcus. The Literature of the United States. Penguin: Middle sex, 1954

[10] Atkins, John. The Art of Hemingway. London: Peter Neville Ltd., 1952.

[11] Benson, Jackson. Hemingway....The Writer's Art of Self - Defense. Minneapolis: University of Minnesota press, 1969.

[12] Hemingway, Ernest. "A Farewell to Arms". Surjeet Publications, 1977.

[13] Tripathi, J. P. Ernest Hemingway: A study in his Evolution. Bareilley: Prakash Book Depot, 1990.

[14] Hemingway, Ernest. "The Sun Also Rises". Surjeet Publications, 1977. 